\title{
Producing prejudice: \\ The rhetoric of discourses in and around current films on Roma-Hungarian interethnic relations
}

\author{
LASZLO STRAUSZ
}

The rhetoric of discourses in and around current films on Roma-Hungarian interethnic relations prevents audiences from positively engaging with Roma characters. My analysis reveals the ways in which the two documentaries broadcast on national Hungarian television on Roma people since 2009 block the channels of identification between viewers and filmic characters. Additionally, this essay examines the rhetoric of the press release issued by the Hungarian Ministry of Public Administration and Justice on the film Just the Wind at the Berlin Film Festival. In the press release the Ministry actively seeks to widen the gap between the racially motivated killing series in 2008 and 2009 against Roma and the filmic representation of the same events, which in fact enables audiences to identify with the victims. I argue that the seemingly different discourses overlap in their efforts to distance the viewer from Roma, thereby contributing to the strengthening of majority society's prejudices against them.

Keywords: Roma, Hungary, visual representation, identification, prejudice, stereotypes

With the strengthening of Hungarian right-extremist political forces and the widespread acceptance of racist language, the formation of audiovisual stereotypes about Roma (certainly not the only minority affected by these changes) needs to be investigated in order to create critical awareness about its proliferation. The reasons for the strengthening of this radical attitude within society are manifold, and I do not claim to propose an explanation for them. However, many researchers locate the origins of post-1989 anti-Roma sentiment in the forced assimilatory programs at the workplace under the Socialist regime, during which Roma were employed in unskilled positions of the lowest prestige and pay. ${ }^{1}$ With the faltering of the state-socialist economy, expendable Roma employees were fired in great numbers. The unemployed Roma, in turn, were perceived by an already prejudiced majority society as criminals and deviants. A 2006 study found that "almost two thirds ( 62 per cent) of the adult population in Hungary agreed fully or to some degree with the following statement: 'The tendency to commit crime is in the blood of the Roma'" (Balogh 2012: 242), revealing the widespread nature of this belief.

1. See Barany (2002), Kemény (2005), Crowe (2007), Szalai (2007), Ferge (2008), Dupcsik (2009).

Laszlo Strausz is an assistant professor at the Department of Film Studies, Eötvös Loránd University, Múzeum krt 6-8, 1088 Budapest, Hungary. Email: laszlo.strausz@gmail.com

Romani Studies 5, Vol. 24, No. 1 (2014), 1-24

ISSN 1528-0748 (print) 1757-2274 (online) doi: $10.3828 /$ rs.2014.10 
With the tightening of the economic crisis after 2008 and the worsening of the economic conditions in Hungary, the scapegoating of Roma intensified. Official and/or institutional voices circulating in the public sphere started to offer deeply problematic accounts of the minority. For example, in a 2009 interview, Máté Szabó, Parliamentary Commissioner for Fundamental Rights, stated that society needs to be warned about Gypsy crimes. After the outcry of NGOs and the President about this statement, the Commissioner did not resign. ${ }^{2}$ The leading right-extremist party Jobbik built central elements of its rhetoric on existing anti-Roma sentiments, and during the 2010 elections received more than 12 per cent of the popular vote. The party's links with the paramilitary Hungarian Guard, itself established in 2007, were entirely open. The Guardists, parading in quasi-Nazi uniforms, organised threatening marches across the country in various villages with a large Roma population, mostly without interference from the authorities. After the banning of the Guard the organisation regrouped as the Hungarian Guard Movement, and continued its inflammatory actions. According to a recent study "one of the most important sources of this shift [towards far-right radicalism] in the Hungarian political scene derives from the dynamics of local politics" (Zolnay 2012: 26). The inability of national politics to develop a long-term strategy for the development of Roma's situation since 1989 has made itself felt on the local level. Thus, "aggressive racist terms (...) and statements of mayors have strongly shaped the topics of public political discussion in the last two or three years (. . .)" (2012: 26), which, in virtue of their authoritative context, have contributed to the growing anti-Roma sentiments.

Taking into consideration the aforementioned tendencies, the audiovisual representation of Roma is an increasingly important factor in the formation of society's attitudes since "the majority of Hungarians do no meet Roma at their workplace (. . ) or in the close proximity of their residence" (Bernát-Messing 1998: 6). Thus, I will illustrate how the rhetoric of the examined films and their surrounding discourses mirror, and simultaneously strengthen and produce, majority society's racist prejudices about Roma-Hungarian relations on various filmic and extra-filmic levels.

When selecting the films for this essay, I used the above-mentioned criterium: the works must depict contemporary Roma-Hungarian interethnic relations. This means that while the films discussed here use two different narrative modes (theatrical and television documentary, fictional feature film), they are based on nonfictional cases of conflict between the Roma minority and the Hungarian majority. Thus, these diverse texts cohere in the sense

2. Other Ombudsmen criticise Máté Szabó, who speaks of Gypy crime. Népszabadság [in Hungarian]. http://nol.hu/belfold/a_tobbi_ombudsman_is_biralja_a_ciganybunozest__ emlegeto_szabo_matet (accessed 12 Sept 2012). 
that they allow insight into the ways textual elements either contribute to the formation of audience allegiances or block the formation of these allegiances towards Roma in general. While I do not claim that all texts in circulation in Hungary today follow this pattern, the three films are representative in the sense that they directly address the problem of contemporary interethnic relations through official, state-run discursive channels.

The first two films I have chosen are Sziven szúrt ország (Country Stabbed in the Heart, dir.: Gábor Kálomista, 2009) and Pesty Fekete Doboz: Cigány-magyar együttélés (Pesty Black Box: Roma-Hungarian Coexistence, dir.: László Pesty, 2012). The former was produced for cinematic release, but after four months MTV1, the first channel of Hungarian National Television broadcast the film at prime time. The latter film was directly produced for television, and similar to Pesty Fekete Doboz it was shown on MTV1 prime time in 2012. Based on the two films' nationwide free broadcast, I think it is safe to assume that these are two films on the topic of Roma-Hungarian interethnic relations that have reached the largest number of Hungarian viewers recently (whether in cinema or on television). Thus the rhetoric of these films warrants our attention if we are to understand the way mainstream television contributes to society's current image of Roma minority. The third film in my selection, Csak a szél (Just the Wind, dir.: Bence Fliegauf, 2012), was distributed in theaters in Hungary. The box-office figures were disappointing, but later the film received the Silver Bear at the Berlin Film Festival. The premiere of the film in Berlin triggered a remarkable reaction by the Hungarian authorities (Ministry of Public Administration and Justice), which partially financed the production. At the press-showing of the film on February 16, 2012, the Ministry distributed a leaflet that suggested to the reporters and journalists how to interpret the film. Thus, these three works and the debates and discussions around them can present a picture of the production and dissemination of audiovisual meaning about Roma-Hungarian relations.

The central problem around the image of Roma (and ethnic minorities) in audiovisual discourses is that they are endlessly described from the point-ofview of majority society: "[r]ather than being given the chance to portray themselves, the Romany people have routinely been depicted by others" (Iordanova 2003). Minorities are spoken for by the majority Self, which repeatedly turns them into Others. Postcolonial theory ${ }^{3}$ has analyzed these positions extensively in relation to the standard Western (Eurocentric) narratives dominating non-Western contemporary cultures. In their seminal work on film and postcolonialism, Shohat and Stam propose that Western discursive power needs to 
be dissected as a set of textual strategies. According to their formulation, the question becomes: " $[\mathrm{w}]$ hat narrative and cinematic strategies have privileged Eurocentric perspectives, and how have these perspectives been interrogated?" (Shohat-Stam 1994: 7). These cinematic strategies, however, are not exhausted by the medium's natural capability to offer authentic or realist representations. On the contrary, "the emphasis on realism has often betrayed an exaggerated faith in the possibilities of verisimilitude in art in general and the cinema in particular, avoiding the fact that films are inevitably constructs, fabrications, representations" (Stam and Spence 1983: 2). These cinematic constructions of "othering" carry complex ideological consequences. Their textual structure needs to be investigated and their functions recognised so that their political implications become clear for viewers.

Speaking of majority society's representations of Roma (and other minority) characters, many authors point out that the prejudiced images are instructive in the creation of the identity of the majority Self. Thus, "[i]t should be clear that in the stories we non-Roma (. . .) tell of Gypsies through literature, film, photography or museum displays, we find ourselves, our desires, fears and preoccupations, our shared and individual ontologies and existential dispositions" (Gay y Blasco 2008: 298). In the insecure milieu of post-socialism, the function of these representations starts to carry a heightened importance, since they come to bear upon the national identity of Eastern European countries, an identity not evident since the end of the Cold War. In this sense, "[ $t$ ]he changing situation of Gypsy, or Romani, minorities within Eastern Europe provides a useful lens through which we can examine how whiteness has been called upon to provide legitimacy to the post-socialist nation-state" (Imre 2005: 80 ). This pattern can be discovered at work in the central stereotype that still governs the representation of Roma: their nomadic nature. Accordingly, " $t]$ he Gypsies' radical Otherness stems from their perceived lack of roots, from the deeply entrenched assumption that they do not belong here but neither do they belong anywhere else" (Gay y Blasco 2008: 299). In consequence, for majority producers and consumers of images of Roma, these representations mean the opposite for the construction of their own identities: the majority Self recognises him/herself as someone who belongs, both in the local and the national sense of the word.

In general, the verbal or visual representations of Roma have remained surprisingly consistent: "[i]n the sixteenth century, as today, the wandering, free, musical, thieving, lustful Gypsy appears at once as uncivilised, animal-like and predatory (. . .); and as generous and noble yet child-like (.. .)" (Gay y Blasco 2008: 298). European cinema has recycled this function of 'othering' in most of its depictions. Iordanova concisely lists the central tropes as "passionate and self-destructive obsessions; 'feast in time of plague' attitude; astonishingly street-wise and strong-willed protagonists; complex patriarchal power struc- 
tures within extended families; mistrust to outsiders; coerced urbanisation, forced integration and imposed conversion away from semi-nomadic lifestyles" (2003). As can be seen, each of the narrative tropes easily fit into the pattern of distinguishing the majority Self from the minority Other. Commercial cinema in general is not interested in the rough realism of Roma-majority interethnic relations. According to Iordanova, the commercially successful, exoticising production and the few "socially conscious feature dramas that are genuinely concerned with the Romani predicament (. . .) will most likely continue to coexist side by side" (2003). It is clear, however, that through their commercial reach the former diminish the cultural-political impact of the latter films.

Hungarian films featuring Roma characters are even more polarised. Commercially successful productions very rarely feature Roma characters. Interviewed producers said that "if they were to concentrate too much on Roma issues it could lead to a situation where a lot of viewers would turn to other channels" (Bernát-Messing 2001). Socially more conscious but commercially insignificant films like Romani Kris (dir: Bence Gyöngyössy, 1998), Dallas Pashamende (dir: Róbert Pejó, 2004) and Vespa (dir: Diána Groó, 2009) use noble, if melodramatic characters that often clash with the mainstream. However, these films regrettably received a limited distribution, and reached only a few thousand viewers. Commercial television channels have featured Roma in talent shows as singers and musicians (Caramel, Laci Gáspár) and in reality shows (Majka), who since then have become media stars. In 2003 the reality show 'My Big Fat Roma Wedding' Roma was so evidently exoticised that the National Radio and Television Authority shut down the broadcasting channel for 30 minutes as a penalty, arguing that the show contributed to the reinforcement of negative stereotypes. The Győzike Show, a reality program about the life of the title character's family, reached a huge number of viewers (at its peak 2.26 million in April 2005), but mostly revolved around the adventures of the clumsy, not very bright upper-class protagonist, whose life had nothing to do with the Roma population's desperate efforts to lead a middle-class existence. These performances entirely fit with the exoticising trope discussed earlier in connection with the representation of Roma in popular media.

In order to avoid the exoticisation phenomenon central to the representation of Roma, in my essay I will focus on three audiovisual discourses that revolve around non-fictional cases of Roma-Hungarian relations. Each of the analyzed discourses deals with actual cases of serious interethnic crises. I will evaluate the rhetorical strategies of these audiovisual representations (shots, angles, color, compositions, depth of field) so that the viewer-character relations established by the texts become visible. Throughout the essay I will refer to the concept of identification, or to use a more precise term, engagement, as described by Murray Smith (1995) in the context of feature films. The term 
engagement seems useful for my project because is allows me to give a nuanced description of the ways in which the films construct the viewers' emotional reactions in relation to the filmic characters.

According to Smith, the term identification has been used to vaguely to describe the relation between filmic characters and the viewer, and proposes instead to use the concept of engagement, within which he distinguishes between the three phases of recognition, alignment and allegiance. Recognition relies on existing knowledge, compiled simply through watching a large number of films that viewers use to identify specific character traits while attempting to arrange these traits into more or less coherent fictional characters or personalities. Thus, recognition is the "spectator's construction of the character: the perception of a set of textual elements, in film typically cohering around the image of a body, as an individuated and continuous human agent" (Smith 1995: 82). This step is followed by alignment, which Smith describes as the "gluing" of the viewer to the character. Through spatio-temporal attachment (how close are we to the character, and for how long) and subjective access (how much do we know about what is going on in the character's head), filmmakers can provide exclusive access to select characters. These elements, however, do not automatically create sympathy in the viewer. As Smith points out, " $\mathrm{t}]$ he phenomenon of allegiance is distinct from those of recognition and alignment in that it is an emotional as well as cognitive response" (1995: 187). Thus, the third stage of engagement, allegiance, pertains to a moral evaluation of the character based on the previous two steps of engagement. To my knowledge, this methodology has not yet been applied to the analysis of the audiovisual representation of minorities. The three phases allow me to conceptually illustrate the way that the contemporary audiovisual discourses analyzed here encourage viewers to recognise Roma characters through a prejudiced lens. Simultaneously the films use textual elements that work against the alignment and allegiance between audience members and Roma characters.

As I will show, the rhetoric of the discourses in question obstructs audience's engagement with select characters by using a rich repertoire of cinematic language to manipulate the viewer. This problem of engagement or identification is all the more pressing since it discourages audiences from constructing complex, multi-sided explanations about the nature of the current conflicts between the Hungarian majority and the Roma minority.

\section{The cases}

Interethnic relations between Roma and Hungarians have become a lot more intense in recent years, and on numerous occasions these tensions were resolved with violence. What I call cases here, on which Country Stabbed in 
the Heart and Just the Wind are based, refer to two homicides where the ethnicity of both the perpetrators and the victims played an important role. The third film, Pesty Black Box documentary, singles out several, less high-profile cases and claims to paint a general picture of Roma-Hungarian coexistence. Nonetheless, this film also focuses primarily on aspects of criminality.

In 2009, the Romanian handball player Marian Cozma, who played for the Hungarian team Veszprém, was stabbed and killed in a fight that erupted between two groups in a nightclub of the same city. The attackers were identified as a group of Roma. As the film was shot the case was still in trial and no verdict was reached yet. Thus, the film produced its own judgement, one that was loaded with prejudice. Country Stabbed in the Heart exercises numerous rhetorical moves that situate the case on the level of Hungarian national identity. The title immediately established the murder as an attack against the entire body of the nation. This inclusive understanding of the nation (of which the Romanian Cozma playing in a Hungarian team is automatically a member) hides the fact that Romanian-Hungarian relations have been, to say the least, problematic for at least a hundred years. Since the 1920 Trianon peace treaty that redrew the map of the entire region, contact between Romania and Hungary has been burdened with mutual accusations and mistrust. Repeatedly, throughout the last century, both nations have utilised these problematic relations to create nationalistic-antagonistic identities for domestic use. What is significant about the film is that it glosses over these issues in order to produce an anti-Roma identity that unifies the nation as a body (including the Romanian athlete playing in Hungary), which was stabbed in the heart. The attackers are depicted as a band of faceless, indistinct criminals who sought out the fight just for entertainment. As depicted by Country Stabbed in the Heart, the clash between the handball players on a night out and Roma attackers was a showdown between the nation and the forces of the dark side. The representational practices of the film disseminate a one-dimensional image of the assailants that encourages the viewers to identify with Cozma and his friends, while generally disengaging from Roma (and not just the attackers). The racist discourse of the film emotionally manipulates audiences by relying on the basic cinematic practices of framing, point-of-view shots, the 180-degree rule, lighting and other techniques.

While Country Stabbed in the Heart focuses on a specific case, the Pesty Black Box documentary intends to paint a general image of Roma-Hungarian coexistence. The film itself is based on an article of István Forgács (2011), the title of which translates as "I don't belong". Forgács is a Roma intellectual who worked for various governmental and non-governmental organisations both in Budapest and Strasbourg in the field of minority policy-making. In his piece, Forgács asserts that he does not belong to Roma if that identity means inten- 
tional unemployment (implied laziness), the lack of respect for private ownership (implied thievery), the bearing of children in adolescent age (implied sexual aberration) etc. Forgács basically maintains that Roma themselves are to blame for their situation within society when it comes to issues of employment, heath, housing and education. According to the article, these conditions will only change if Roma do something about it, and majority Hungarians bear no responsibility for the fact that Roma occupy a terrain on the fringe of society. His article has been widely used to justify implicitly and explicitly racist positions against Roma.

In the film itself, Forgács visits various characters or institutions to propagate his position, and Pesty's film can be described as an audiovisual illustration of Forgács's theses. The manipulative techniques of the film paint an image of Roma that attempts to confirm the prejudiced propositions presented. A majority Hungarian viewer of the Pesty Black Box documentary not only has the option to completely disengage from the problem of the situation of Roma (they are to blame for their situation, and only they can solve it), but can also feel relieved that their existing prejudices are well grounded. This response resurfaces repeatedly in the film, the techniques of which need to be dissected and analysed on the level of shots, angles, framing and lighting. While Country Stabbed in the Heart produces positive engagement with the handball players and negative identification with the assailants, the Pesty Black Box film onesidedly presents Forgács's theses according to which Roma's deficiencies fully explain their exclusion from contemporary Hungarian society. This prejudiced position is reinforced by the representational practices of the film, which can be described along the notion of audiovisual distancing resulting in emotional disengagement.

Bence Fliegauf's Just the Wind is the semifictional interpretation of one case in the racist killing series of 2008-2009, during which right-extremist assailants attacked Roma families' houses in small villages during the night with firebombs and shotguns, killing six people. The hunt went on for sixteen months, and by the time the suspects were caught, they had attacked on seven different occasions. Fliegauf's film is loosely based on one of these attacks, and depicts one day in the life of a Roma family immediately before the attack. Although Just the Wind does not present new themes of Roma existence and seems to recycle topics of many other productions (oppressed Roma children in school, Roma women terrorised by coworkers, intercity buses not stopping for Roma), it is still an immensely important work because it allows for the audience to positively engage with the characters. This, to a large extent is the result of the film's visual strategies, such as a handheld camera, tight framing and close shots. In contrast to the two previous documentaries, Fliegauf's feature bonds the viewer first visually, and as a result, emotionally, with the Roma 
victims; a characteristic seen rarely in Hungarian fiction films. What makes it important from the aspect of the production of prejudices is the previously mentioned intervention of the authorities in how Just the Wind is to be interpreted. The discourse I am about to analyse, therefore, is not just the film itself, but rather the way the Ministry aimed to frame it. The press release is a vivid example of how the discourse of the authorities identified the events as an isolated occasion, thus downplaying the structural significance of the systematic killing spree against Roma families. The press release indirectly contributes to a separation of crimes committed against Roma and non-Roma citizens, thus leading to discursive segregation.

The essay thus pertains to the filmic texts of two documentaries and a fiction film, and a press release on the third film by one of the co-financing institutions. My analysis of the discourses shows how they contribute to the production of prejudices against Roma. While I do not offer any interpretation of the intentions of the enunciators (the two options are ignorance or racism), the mere fact of the existence of this discourse should make it clear that mainstream speech about Roma in Hungary normalises biased, prejudiced thinking.

\section{Whose country?}

The deeply problematic makeup of Gábor Kálomista's Country Stabbed in the Heart consists in how the film overgeneralises and emotionalises a single criminal case depicting it as an attack against the entire nation. Ultimately, the film contributes to an ethnic understanding of the nation, from which Roma are by definition excluded. In order to understand the ways in which it attempts to create emotional response in its audience, I will break down the double rhetorical move of the film, which simultaneously individualises the victims and depersonalises and objectifies the attackers.

In Country Stabbed in the Heart, the textual elements across the three phases of engagement cohere around and point towards the two easily identifiable, Manichean poles of good and evil. Kálomista's film immediately gets to work to establish these opposites as dominant in the representation of both groups. In the opening scenes, audiences are introduced to the city of Veszprém and its handball team, MKB Veszprém, by intercutting well-crafted stock footage of the city with fast-paced action shots of the celebrated and widely popular players during a game. The romantic image of the players establishes them as successful athletes who compete for the glory of their community. The close bond between the city and the team foregrounds the implicit connection between team and nation already established in the title of the film. ${ }^{4}$

4. For the connections between sports and national identity, see Tomlinson and Young (2006), Bairner (2001). 
After the introductory sequences, the athletes reappear in the Veszprém handball arena, but this time to participate in a grieving ceremony. Team members line up in a semicircle at one end of the handball court with a single rose in their hands. Cozma, the deceased player, is laid out in the goal, while his teammates say farewell to him. The camera carefully follows the emotions of the weeping players in close-ups, and from time to time it cuts to long shots revealing the entire team in the otherwise empty stadium. The entire scene is recorded with a steel-blue tint that sucks the color out of the images, further foregrounding the tragic character of the event. By following images of the peaceful city with this sequence covering the grieving team, the filmmakers push viewers towards the conclusion that the life of Veszprém, and by extension that of the nation, has been thrown out of balance. This emotional conclusion is reached without any detailed introduction of the attack itself. Viewers have already recognised the handball team as important narrative agents; they have been aligned with them through the film's textual elements detailed above; and they have pledged allegiance to the team since it is synechdochically depicted as a stand-in for its own community. While Smith does not rule out the fact that the viewer can engage with characters antagonistically opposed to those she has already morally identified with (allegiance), we will see that Kálomista's film will not attempt to do this. Rather, Roma attackers are introduced as faceless characters whose narrative function is to interrupt the idyllic bond between the community and the handball team.

As prejudiced as the film is, it does not even attempt to hide its conception of collective Roma guilt. Sequentially, the film attempts to distress the viewer by a shock-pause-shock-pause structure: tranquil and sorrowful images of the victims are systematically followed by fast-paced, menacingly composed shots of Roma (recorded in an entirely different situation). In this vein, after the talking head shots of Cozma's father, who sympathetically explains how his son's career has done something for the betterment of Romanian-Hungarian relations, the film turns to construct an image of the attackers as the 'dark side.' Alongside pumping electronic music, a graphic appears that introduces the handball team and the 'dark side' similar to the competitors of a boxing match. From the left and right side of the frame, two masks - as two gates - with logos close in on a shot of the Veszprém fans cheering on their team (see Figures 1.1 and 1.2).

On the right, the filmmakers place the logo of the handball team, while in the left logo we can see the figure of a hooded person, drawn in a dark tone, smashing a section sign (the rule of the law) with a fist. The same graphic appears on many other occasions, serving as a transitory element between various scenes, thus trying again and again to establish the crime as a showdown. In this first instance, however, the murder is already depicted as a full- 

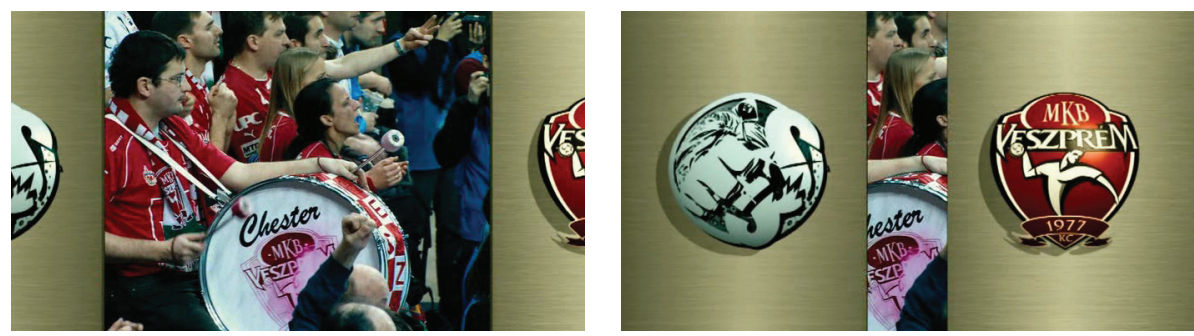

FIGURES 1.1-1.2. The showdown between evil and good forces

scale confrontation between good and evil forces. In a few seconds, the same logo with the hooded figure appears on the full screen accompanied by the words 'dark side.' Immediately, the filmmakers cut to a screen shot of a YouTube page bearing the title "Gypsy terror in Siófok". ${ }^{5}$ The event, which the film uses as a reference point, has nothing to do with the Cozma murder, but rather serves the purpose of constructing an image of the Roma as the dark side. Accordingly, the film infers that Roma in general are responsible for the death of the Romanian athlete. Each of the mentioned textual elements supports our recognition of Roma as criminals. However, we know close to nothing about the attackers. The film spatially and temporally keeps its distance from them. Thus, no alignment between viewer and filmic character can take place. This in turn also prevents insight into their motivations. In terms of the ideology of nation, an identity is established here based not on a political or cultural basis, but exclusively on ethnicity. According to the logic of Country Stabbed in the Heart, Roma have scarred the body of Hungary. Implicitly, the film reasons that through their criminal behavior Roma have excluded themselves from the community of the nation.

Central to the entire documentary are the reenactment scenes of the murder in the Veszprém nightclub. This part of the film is structured by talking head shots of one of the attacker's defense attorney, and a leading official of the handball club. The two men offer two competing versions of what happened in the night club, directly contradicting each other on various key points. The two accounts are intercut following the timeline of the evening, but additionally the filmmakers used three types of reenacted material: colored scenes, and black and white scenes with live actors, and 3D graphic illustrations of the same events.

5. The video on the YouTube page is CCTV footage recorded in Siófok, where - allegedly Roma criminals from the small town of Enying held a power demonstration in an effort to try to take over control over some shops in the area frequented by tourists. According to the police, no connection can be established between the attackers of the Veszprém case and the march of Siófok asides from the fact that some members of both groups resided in Enying. Nonetheless, he film automatically connects the two groups, creating the impression that the attackers are organised criminals. 

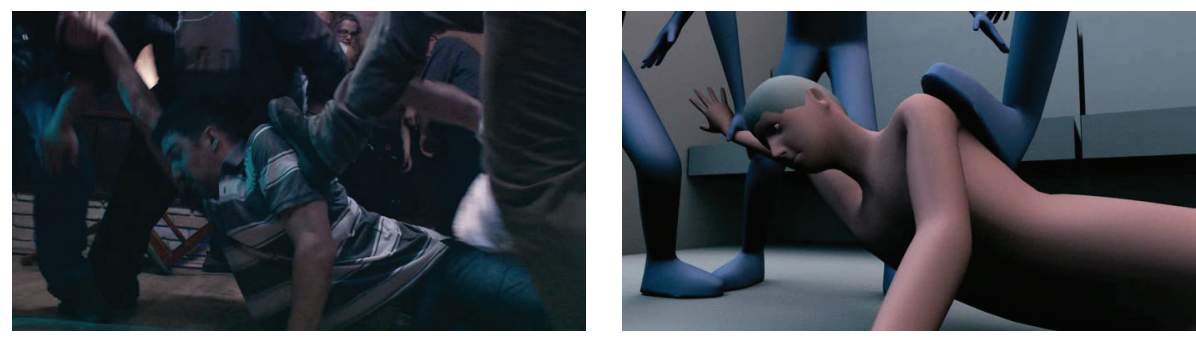

FIGURES 2.1-2.2. Live-actor and graphic illustration of the events: the club official's version

The colored live reenactment and the graphic illustrations depict the same version of the details of the crime (see Figures 2.1 and 2.2). However, the illustrated version is that of the handball club official, and not the defense attorney. The filmmakers do not bother to attempt to keep up the appearance of impartiality: Country Stabbed in the Heart accepts one of the competing stories without hesitation, and supports this version with additional materials. On the one hand, the reenactment featuring live actors psychologically brings the viewer into a closer contact with the athletes, who were in fact played by famous Hungarian actors seen in popular comedies and romantic melodramas. ${ }^{6}$ At the same time, the actors playing the attackers are not recognizable, and the end titles help little in this sense, because it simply catalogues all contributors (cast and crew) in one long list without any indication of their role in the production. On the other hand, the graphic reenactments create the impression of scientific objectivity. In these illustrations, Roma are depicted in blue, while the athletes appear in red. The cold and the warm colours further influence the engagement of the viewer with the two parties in the confrontation.

The third type of illustrative material is the black and white live reenactments. These images are preserved for the sequences depicting the Roma attackers arriving at the nightclub (note how the reenactments depicting the athletes were all shot in colour). When the handball club official mentions that when looking at the surveillance camera tapes, one can recognise a large group of young Roma arriving at the club, the film cuts to a black and white shot that looks like surveillance camera footage with a low quality, grainy, high angle shot possibly recorded by a small industrial camera fixed to the ceiling (see Figure 3.1), but this is never actually confirmed by the film. There is no information in the film about the status of these images, whether they were recorded in the club at the night of the crime or not. However, intercut with the words of the club official, the images have the capacity to underscore his version of

6. Csaba Pindroch, Szonja Oroszlán, Sándor Csányi and Simon Szabó reportedly knew exactly what production they are taking part in and received no payment for their roles since it was considered "just a documentary". 

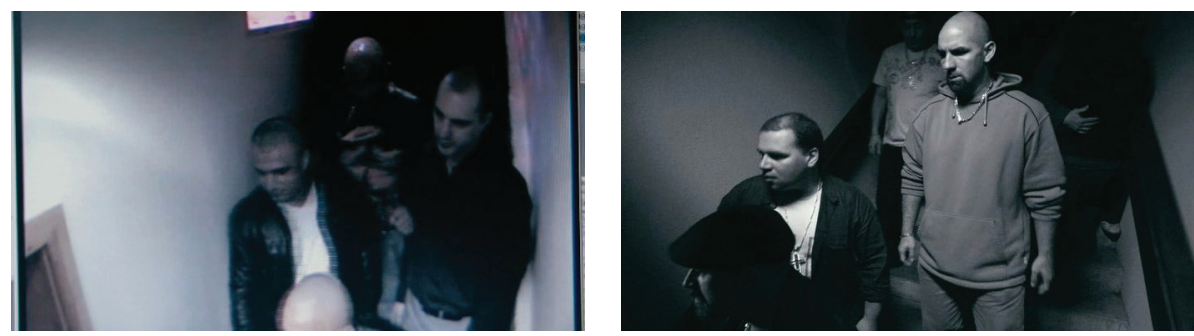

FIGURES 3.1-3.2. Surveillance footage or reenactment: the sources of these images are not identified

the events. The status of these images becomes even more problematic, when later the filmmakers emulate the effect of a surveillance camera, but this time the shots are clearly reenacted with Extras. While the angle in both shots is the same, the second sequence features various light sources and is recorded with a camera of much better quality (see Figure 3.2). In the film, however, both shots serve to underscore the club official's recounting of the night's events. Without identifying the sources of the different black-and-white shots, they are inserted into the film together with the club official's monologue. When the defense attorney offers the version his clients give of the events, no audiovisual illustration is offered.

The textual elements of the film aim at encouraging audiences to convict the attackers - before the court ruling. Country Stabbed in the Heart not only mirrors dominant prejudices in Hungary against Roma, but also actively contributes to the creation of these prejudices in various ways. First of all, it introduces the attackers as faceless criminals (cinematically: without close-ups, faces and eyes unlit) and thus overgeneralises Roma criminality. Secondly, while viewers recognise the narrative function of both groups of characters, alignment and allegiance are textually blocked in relation with Roma characters.

\section{Which coexistence?}

As a film presenting the relations of two ethnic groups, it is quite telling that Pesty Black Box: Roma-Hungarian Coexistence begins with an apologetic gesture of a Roma priest: as he puts it, he wants to "apologize for the sins committed by Roma against Hungarians." Immediately, the filmmakers make it clear that their understanding of the "Roma-question" is deeply asymmetrical: Roma have to change, accept the norms of Hungarian society etc. in order to successfully assimilate. This position, adapted from the 2011 article of István Forgács, a Roma intellectual who is one of the narrators of the documentary, characterises the entire film. The visual rhetoric of the film powerfully communicates this position to the viewer by depicting Roma collectively as primitive, 
ignorant, aggressive and as a result of the above, extremely poor. As a general conclusion, the film states that Roma first have to develop the will for change to positively alter their situation within society, which is "waiting" for Roma who lag behind. Therefore, narratively, the viewer disengages from Roma. In the following, I will list the most visible textual elements that contribute to this disengagement.

Early on in the film, Pesty the director and Forgács visit Attila Lakatos, a Roma community leader of Borsod County in the eastern part of Hungary. Lakatos surprisingly shares the filmmakers' stance on the causes of Roma's situation. Lakatos and Forgács together narrate much of the first two-thirds of the film. While the two men explain their position on questions like the high fertility rate among Roma, the allegedly disproportionate number of Roma in prison populations, or Roma's problematic relation to work and employment, the film composes its images in order to communicate to the viewers that these men can be trusted. To return to Murray Smith's categories, the audiences' alignment and allegiance with them is textually assisted. All of the men are comfortably seated in a large living room. The rhythm of each scene is easy to follow: longer shots give way to close-ups (see Figures 4.2 and 4.3) as the speakers articulate the most important elements of their position on the discussed issues. The distribution of the light within the frame is visibly not spontaneous. We can discover traces of the three-point lighting technique: this setup directs the viewer's attention immediately to the faces and eyes of the characters so that their emotions can be discerned easily. The otherwise evenly
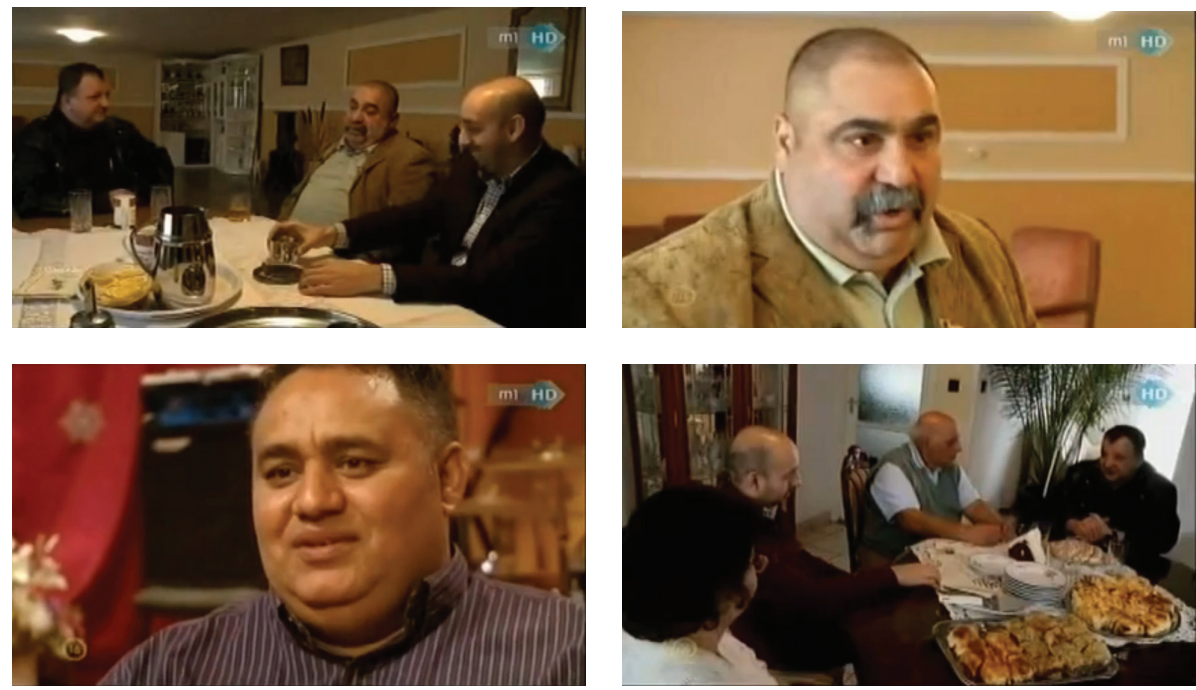

Figures 4.1-4.4. Images of warmth: Pesty, Forgács, Lakatos and Kovács speaking on Roma responsibility 
distributed light has a warm, orange tone further strengthening the impression of a friendly family home (see Figures 4.1 and 4.2). In a different scene at Forgács's parents' house, audiences are presented with images recorded in the same style, but here the dinner table in the middle of the shot is covered with food and drinks, visually welcoming not only Pesty, but the viewers as well (see Figure 4.4). Pesty is repeatedly framed within the same shot as Forgács's parents, bringing them together on a shared platform, compositionally and argumentatively. This technique is even more visible in the last third of the film dominated by conversations with Roma priest Edgár Kovács: the dialogue is recorded using over-the-shoulder shots, which also unite them visually. These compositions, allowing for viewer-recognition with the characters, are sympathetic, normalising the imagery and thus emotionally endorsing their position on the questions discussed.

These images stand in strong contrast with the visual rhetoric of the compositions depicting Roma individuals and communities. In line with the main point of the film, according to which only Roma need to change so that they are accepted by majority society, the film exaggerates their situation by visually depicting their world as a catastrophic emergency zone. Shots of interviewed Roma are recorded in dark run-down rooms, with each character standing against a tight corner, their faces cut up by dark shadows. As Forgács reads out parts from his original article, his theses are illustrated by the filmmaker in a montage scene using shots of run-down villages, children kicking and beating each other, houses standing alone in the middle of nowhere, zoom-ins on a toilet in a corner of a room, a man carrying his child on his back across a village main street, fires burning in barrels and smoke rising from between the houses of some village, children running around in the house naked or barefoot, close ups of dirty dishes in the sink etc. Meanwhile we hear Forgács's words:

I don't belong to you, if you think having many children at a young age and among miserable circumstances is a cultural right and a value. I don't belong to you, if you don't want to know about domestic violence on the Gypsy row, about the large number of Gypsy kids in state care or convicted Gypsy men in Baracska [an infamous prison] (...) $[\text { Author's translation }]^{7}$

An ominous, spherical, high-pitched female chorus, the tempo of which accelerates throughout, complements the montage sequence. Repeated, blaring distorted electric guitar riffs accompany this chorus. The fast and disharmonious music further strengthens the viewer's negative impression. Contrast here becomes an important constitutive element in the representation of the two

7. Original in Hungarian: "Nem tartozom közétek, ha szerintetek fiatalon szülni, és a nyomorba sokat szülni kulturális jog és érték. Nem tartozom közétek, ha a családon belüli erőszakról nem akartok tudni a cigánysoron, vagy arról, hogy mennyi a cigány-gyerek a lelencben, az elítélt cigány férfi Baracskán." 

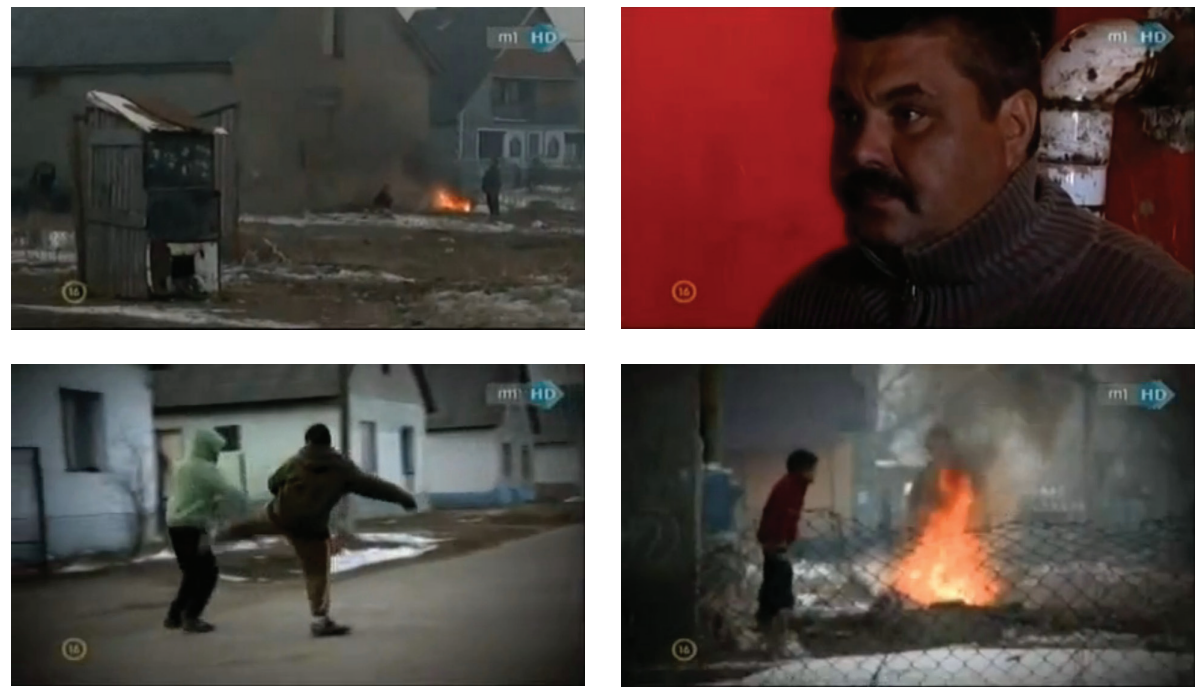

FIgURES 5.1-5.4. The visual ghetto

sides: this tense, fast paced music always stops when the filmmakers cut back to Forgács, or any other person condescendingly speaking of Roma. When Forgács speaks, at the end of his sentences we can hear a bell toll effect underscoring the seriousness of his character, the graveness of the problem, and the weight of his sentences. Transitions between shots are provided by quick, sensationalising fades to white that look as if someone had released a strong photographic flash on the entire scene. On top of heightening tension, these effects objectify Roma whose life is observed by the film cameras.

The ways in which the film produces prejudiced meaning about Roma is complemented by occasions where majority society's racial stereotypes are being visually naturalised. Towards the middle of the film, Forgács is recorded lecturing to the students of a Police academy. The scene is troubling in itself, because the prejudiced opinion of Forgács is offered without counter-arguments to young, future police officers who probably will have to deal with many ethnic confrontations in their careers. In his speech he states that "according to recent studies, $60-70 \%$ of the members of the police force are prejudiced against Roma ... but $60-70 \%$ of Hungarian society is also prejudiced against them, therefore you don't need to feel ashamed!" Throughout these sentences, the film switches back and forth between close-up shots of individual police academy students, and wider, longer compositions taking in the entire room. In the closer shots, the shallow focus of the compositions (the lack of depth of field in the shots blurs out the background) constructs images of the students' contemplative faces considering or weighing Forgács's words. Regularly, these closer shots are followed by the longer takes with a significantly larger depth 
of field, which is important because in these shots most students are seen nodding, that is, collectively agreeing with the lecturer's point-of-view. Thus, individuals who might have doubts about the lecturer's words are "convinced" by crowd shots. Thereby, visually the viewer is confronted with a situation where Forgács's argumentation proves convincing to the listeners.

After the scene, the film returns to its bombastic montage of catastrophically run down places accompanied by ominous music (see my description on pp. 9-11). The juxtaposition of the two sequences constructs biased meaning in the sense that it serves as an explanation of the existing aversions of majority society against Roma. Sequentially, the sequence "explains" why 60 per cent to 70 per cent of Hungarians think about Roma with racist preconceptions.

On top of the rhetoric of the images, the questions that the filmmakers direct at various characters serve the purpose of supporting the preconceived ideas of Pesty and Forgács. Similar to the contrast between the images creating or blocking engagement, the types of the questions change as the film moves back and forth between subjects accusing Roma for their situation, and Roma themselves. When Pesty is sitting with Forgács's parents (see Figure 4.4), he always asks them open-ended questions that follow the "what do you think about ..." pattern. This allows them to speak in full sentences about their experiences, elaborate on their opinion and argue for their validity. Each of these elements furthers our allegiance with the majority point-of-view. When Pesty interviews a Roma character in his home (for example the man in Figure 5.2), his question immediately changes to a manipulative format, which barely hides his own prejudiced views. Examples for this type of question include "having many children wasn't such a good idea, was it?", "so you're saying that Roma steal?", "so this creates conflict?" and "Roma are romanticising prison terms?" While it is easy to see that each of these questions can only be answered with a yes or a no, these inquires are designed only to be confirmed by the interviewees. Pesty systematically lets the short replies ("Yes!") ring out as the last words of his shots or scenes. The fact that he does not add anything to these phrases, but is shown listening to his subjects in silent agreement, produces the impression that finally the conversation has articulated an important point about RomaHungarian relations. An additional good example for this strategy arrives with the angry outburst of a young woman who says that Gypsies who steal "should be beaten up!" Pesty, again, is seen simply sitting silently and nodding.

The film appears to locate several important problems, but does not even attempt to offer a solution to them. For example, the film skates over the question about the differences in Roma-Hungarian relations in the Eastern and Western parts of Hungary. While coexistence is made to look unproblematic in Zalaegerszeg (located in the West), where Forgács's parents live, the film 
overgeneralises criminality, unemployment etc. among Roma in the East. After establishing the issue, not a single question is asked about the possible causes for this geopolitical imbalance. The disinterest of the filmmaker reveals that he is not really looking for explanations, but rather invests in the repetition of a prejudiced point-of-view. I have found two examples in the film suggesting ways to deal with Roma-Hungarian confrontations, but even these are based on simplistic, authoritarian solutions. In the first, Lakatos, a Roma community leader of Borsod County recounts an event during which he dissolved a building conflict between Roma and Hungarians by simply showing up and telling everybody to calm down and go home. As the story shows, this solution does not engage with possible causes for the conflict. In the second instance, the priest Edgár Kovács offers faith as a way for Roma towards better social and economic status. While this solution might be viable for those receptive to the teachings of Christianity, it lacks entirely the social dimension in which the issue of Roma-Hungarian relations emerges.

The image of alleged coexistence created by Pesty Black Box could be more accurately described as an image of segregation. Pesty's film encourages the viewer to recognise Roma as an ethnic community fully responsible for its own catastrophic economic, health and educational situation. However, by siding with Forgács, according to whom only Roma can do something for the betterment of their position, the film alleviates majority viewers from imagining themselves as prejudiced, and simultaneously blocks viewer alignment and allegiance with the minority characters.

\section{Whose film?}

The controversy around Just the Wind unfolded at the première of the film at the Berlin Film Festival, where it later won the prestigious Silver Bear prize. This film is significant, because unlike Country Stabbed in the Heart or the Pesty Black Box documentary, Fliegauf's work encourages audiences to positively engage with the Roma characters of the film. As the victims of a hate crime series, the protagonists are killed by the end of the film - with one exception. This means that the identification of viewers with the film characters is brutally interrupted. This disruption, however, inspires its audience on one hand to emotionally experience the breaking up of its bond with the filmic characters and, on the other hand, to rationally relate this experience to the non-fictional events the film is based on.

In the following I will show how that the controversy arose when the film was framed by Hungarian cultural authorities as a fictional depiction of an isolated event, thereby lessening the event's significance as a racially motivated series of crimes directly targeting Roma minority. The rhetorical strategy of the 
Ministry of Public Administration and Justice with its press release ${ }^{8}$ had been the deflection of attention from the topic of the film itself and from the general media representation of Roma. Instead, the material works along direct political goals of the Hungarian government by foregrounding - as it claims - the many steps it has undertaken to help Roma minority in Hungary. Thus, Just the Wind was caught up in the authorities' attempts to positively convey their own image to the international media, instead of - for example - triggering debates about the role audiovisual media play in the creation of prejudices. Ultimately, this move results in a cynical passing up of the opportunity Just the Wind offers viewers to face their prejudices.

Just the Wind's language glues audiences to the diegetic characters by creating immediacy through various camera techniques. First of all, the camera never leaves the immediate surrounding of Mari, the mother, and Anna and Rió, her two children, who reside in a small village inhabited by Roma. As they make their separate ways through their day, we are constantly right next to, or behind them. The individual storylines are intercut in order for the viewer to witness what is happening to the three of them over the same period of time. Over-the-shoulder or frontal close-ups make up much of the scenes, during which Mari goes to work picking up trash in a highway rest stop, arrives at an elementary school to clean toilets, and finally returns home to take care of her family. At the same time Anna attends school, walks back home and looks after the daughter of a neighbor. Meanwhile Rió skips school to loaf about in the forests; we see him building a hideout where he stocks food, buries a dead pig, vents anger and frustration by beating the bushes with a stick. Each sequence provides insight into their degrading daily experiences, or the lack of perspective in their lives. While the viewer recognises and constructs their characters as humiliated Roma living in contemporary Hungary, who make plans to leave their home to follow the father of the family already working abroad, the film continues to align viewers with them both spatially and temporally. This alignment is the result of the mentioned over-the-shoulder shots, which do not collapse the viewer's perspective with the characters' point-of-view entirely, but rather unite them in the same image: we see the characters and what they see in the same shot. To enhance this effect, the shaky, handheld camera remains mobile throughout the entire film. Thus, audiences feel as if they are walking just a step behind or in front of Mari, Anna or Rió. Additionally, the depth of field in the images remains consistently shallow: with this technique the filmmakers direct the viewers' attention to those parts of the compositions which

8. Ministry of Public Administration and Justice. 2012. Background material for the film Just the Wind by Bence Fliegauf. Press Release. Scans of the original can be found at pusztaranger.wordpress. com/2012/02/16/seltsame-flugblattaktion-des-staatssekretariats-fur-soziale-integration-auf-derberlinale (accessed 12 Sept. 2012). 

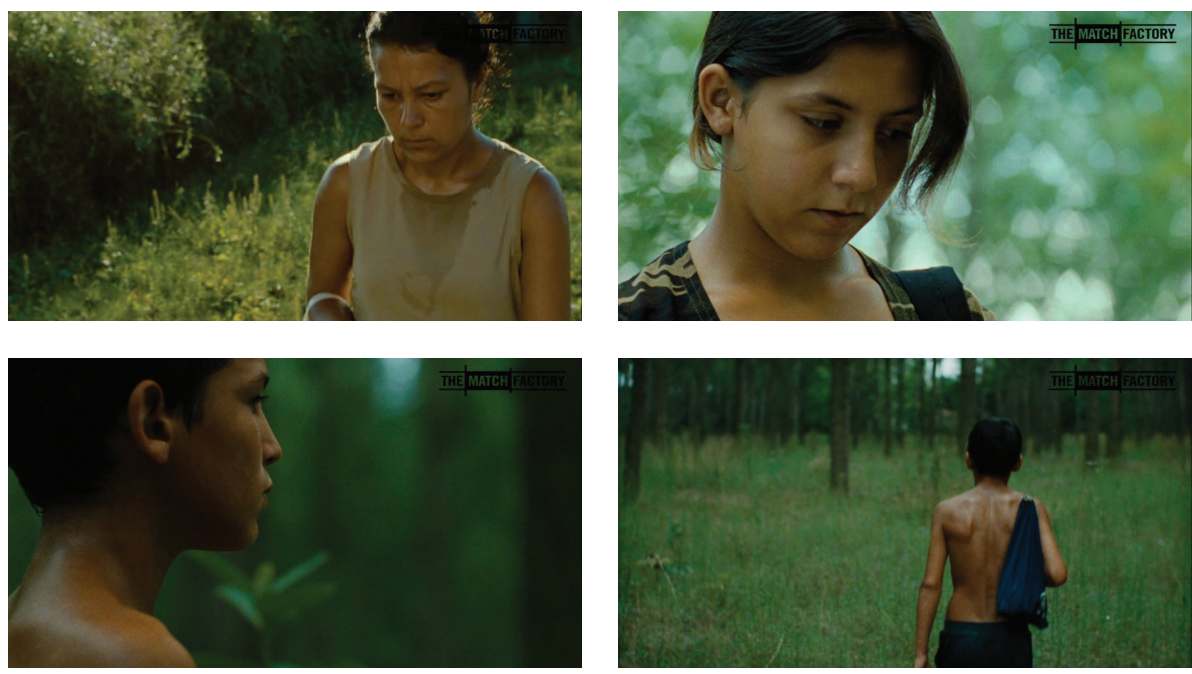

FIGURES 6.1-6.4. Viewer alignment with the protagonists: when and where will the attack take place?

are sought out by the three central characters, but also express their isolation in a hostile world surround them.

While these visual techniques have the capacity to position the audiences in relation to the protagonists, they are also responsible for the suspense created by the restricted narration. The information accessible to the viewers is exactly the same as for the filmic characters: the tight over-the-shoulder shots, the shallow depth of the images and the mobile, handheld frame prevent us from knowing more than they do (see Figures 6.1-6.4). Thus, the central dramatic question of the film - when will the attack against the family take place - keeps audiences at the edge of their seats. It is obvious that the assault will happen, and the alignment of the audience with members of the family results in an effect of suspense, withholding information about the already suspected outcome.

Eventually, as darkness descends on the village and the protagonists are ambushed, the camera panics just as the characters, and runs out of the house with Rió. We only find out that he survived the attack when in the final images of the film, we see that he is not laid out in the morgue: the mutilated bodies of his mother, sister and their grandfather, however, are seen being prepared for the funeral. According to some critics (e.g. Gyenge 2012, Hlavaty 2012), this last scene is unnecessary and sensationalist as the viewer already knows what happened to the family. This view, however, does not take into consideration that the images are indispensible for viewer engagement and the creation of allegiance between the victims and audience After being faced with the executed 
and laid out Roma family, it is not possible to escape the pressing question of the role racial hatred plays in the segregation of Gypsies in contemporary Hungary. Fliegauf's film thereby constructs positive character engagement by allowing audiences to consecutively move through the phases of recognition, alignment and allegiance bonding them with Roma protagonists.

The press release of the Ministry of Public Administration and Justice, however, downplays the importance of the film by sidetracking the discourses around it. Instead of using the opportunity Just the Wind offers to address issues of the representation of minorities in mainstream media, the Ministry's press release highjacks the film and uses it for political purposes, i.e. the polishing of the image of the Hungarian authorities. The rhetoric of the text released for journalists present at the Berlin premier attempts to create the impression that Fliegauf's film is an entirely fictional work, and thanks to the current government's policies, the reality in Hungary is entirely different. This indirectly racist and opportunist gesture belittles the efforts of the filmmakers to open up discourses about Roma-Hungarian relations.

The text of the release consists of four parts: (1) a description of the murder series and the investigation of the authorities; (2) the actions of the Hungarian authorities to help the families of the victims; (3) a range of European examples on current racially motivated crimes; and (4) a list of the efforts of the government to improve the situation of Roma. This structure exercises the rhetorical tactic of "zooming out" from the actual problem, thereby detouring the discussion about problems of interethnic relations thematised by the film. In the second sentence of the press release, the Ministry states that Fliegauf's film is a "fictionalized rendition, and does not follow the events as they happened." While this is true (a title in the opening credits makes this clear), as one of the opening phrases of the text it evokes the impression that the Ministry attempts to further widen the gap between the real events and their audiovisual representation. By repeating something already stated by the director, it appears that the officials who scripted the text have no conception of the ontological differences between a real-life event and its artistic rendition. As the commentaries ${ }^{9}$ reveal, the attending journalists were disturbed by the Ministry's investment in furthering its own political agenda at the premier of the film.

In the next section of the text, the release emphasises that the families of the victims could move into new houses as a result of an international aid cam-

9. For the reaction of the German press, see 'Incomprehension of the Hungarian leaflet action' (in German) 3Sat. www.3sat.de/page/?source $=\% 2$ Fberlinale\%2F160611\%2Findex.html; 'In the heat of the day' (in German) Tagesspiegel. www.tagesspiegel.de/kultur/berlinale-filmjust-the-wind-in-der-hitze-dieses-tages/6220062.html or the video of the Hungarian website Origo about the press conference, which records the question of the reporter of Frankfurter Allgemeine Zeitung videa.hu/videok/film-animacio/csak-a-szel-sajtotajekoztato-fliegauf-bencebwWP9QzPc1mPkniJ (accessed 19 Sept. 2012). 
paign joined by the Ministry. Again, this statement foregrounds the authorities' avoidance of the problems that might have lead to the racially motivated serial killings, but rather engages with the tragic results of the attacks (i.e. dismembered, homeless families). When the text arrives to the list of examples of racist crime all over Europe (including recent attacks in Norway, Slovakia and Germany), the deflecting strategy of the text becomes entirely obvious. Instead of talking about the possible reasons of the phenomenon of racist crime in Hungary (for example, as I suggested earlier, racist representations of Roma broadcasted in primetime television), the release tastelessly points at other similar examples in order to relativise and broaden the geographic scale of contemporary hate crime. Needless to say, this list adds little to the understanding of Roma-murders of 2008-2009 in Hungary. Finally, the press material lists the government's policies to structurally improve the economic situation of Roma. While it remains to be seen whether the actions of the current government taken in the last two years will positively affect the lives of Hungarian Roma, discursively this move reflects a complete indifference about the problem of representation at hand. The government might have created a State Secretariat for Social Inclusion, as the text proudly asserts, but one is left wondering what this institution does if it does not raise its voice when racist representations continue to dominate the image of Roma in Hungarian media. The press release displays that the Secretariat has no conception of how it could actively participate in the creation of positive representations of Roma, thereby attempting to change widely held stereotypes on the minority in question.

The rhetoric of the press release attempts to appropriate the film, in part financed by the Ministry, and situates it in its own political agenda. Since the authorities attempt to contextualise the work within the framework of government policies, the question of ownership surfaces here: whose film is Just the Wind? The press release treats the film as an in-house production of the Ministry, the function of which is apparently determined by the political needs of the cultural- and minority policymakers. However, this attempt brings to surface the complete disregard of the authorities on the pressing questions addressed by the film itself. After the press release scandal, the Ministry, in yet another press release,${ }^{10}$ tried to retrospectively emphasise the importance of Fliegauf's piece for the normalisation of Roma-Hungarian relations. This action, however, can only be interpreted as a stab at saving what was lost by the Ministry's original material distributed at the premier.

10. This press release was not translated into English or German, the Hungarian original can be found at www.kormany.hu/hu/emberi-eroforrasok-miniszteriuma/tarsadalmi-felzarkozasertfelelos-allamtitkarsag/hirek/a-kultura-erejevel-kell-harcolni-tarsadalmi-kirekesztes-ellen (accessed 19 Sept. 2012). 
As I have tried to show, the two documentaries broadcasted on Hungarian National Television (and thus reaching large segments of the public) prevent audiences from positively engaging with Roma characters. As my analyses reveal, after constructing their characters as poor Roma, the films textually shut down channels of spatial and temporal alignment. Thus, the viewer's allegiance with Roma characters is discouraged, which in turn contributes to the impression that primarily they are to blame for their social and economic status. Through the example of Just the Wind, I displayed how positive character engagement with Roma can be established by textual cues in an audiovisual context. While Fliegauf's film is a tremendously important social text, its boxoffice figures were disappointing, and until September 2012, it has unfortunately not been shown on television in Hungary. Additionally, the rhetoric of the co-financing Ministry's press release on the film at the Berlin Film Festival revealed that the authorities are not interested in using the opportunity Just the Wind offers to open discourses on representation, stereotypes and racism. Instead, the release appropriates the film for the purpose of polishing the government's image internationally, an attempt that evidently backfired. In contemporary Hungary, the production of prejudice in discourses in and around current films on Roma-Hungarian relations is running in full force.

\section{References}

Bairner, Alan. 2001. Sport, nationalism, and globalization. Albany: State University of New York Press.

Balogh, Lídia. 2012. Possible responses to the sweep of right-wing forces and anti-gypsyism in Hungary. In: Stewart, Michael, ed. The Gypsy 'menace': Populism and the new anti-Gypsy politics. London: Hurst \& Co. 241-65.

Barany, Zoltan. 2002. The East European Gypsies. Cambridge University Press.

Bernáth, Gábor, and Messing, Vera. 1998. Cutaways, muted: Roma in Hungarian media. Report of the National Office for Ethnic Minorities [in Hungarian]. mek. oszk.hu/o010o/o0144/o0144.pdf (accessed 19 Sept. 2012).

- 2001. A Roma character in Between Friends: The first swallow [in Hungarian]. Médiakutató. 2: 1. www.mediakutato.hu/cikk/2001_01_tavasz/o1_roma_szereplo_ a_baratok_koztben/o1.html (accessed 19 Sept. 2012).

Crowe, David. 2007. A history of the Gypsies in Eastern Europe and Russia. London: Palgrave-Macmillan.

Dupcsik, Csaba. 2009. A magyarországi cigányság története [in Hungarian]. Budapest: Osiris.

Ferge, Zsuzsa. 2008. Is there a specific East-Central European welfare culture? In: van Oorschot, Wim, Opielka, Michael and Pfau-Effinger, Birgit, eds. Culture and welfare state: Values and social policy in comparative perspective. Northampton: Edward Elgar Publishing. 141-61. 
Forgács, István. 2011. If you are Gypsies, I do not belong to you [in Hungarian]. hirszerzo. hu/velemeny/2011/10/10/20111010_forgacs_istvan_ciganysag (accessed 19 Sept. 2012).

Gay y Blasco, Paloma. 2008. Picturing 'Gypsies': Interdisciplinary Approaches to Roma Representation. Third Text 22(3): 297-303.

Gyenge, Zsolt. 2012. Something reeks [in Hungarian]. Revizor. www.revizoronline.com/ hu/cikk/3873/fliegauf-bence-csak-a-szel-62-berlinale (accessed 19 Sept. 2012).

Hlavaty, Tamás. 2012. In the gate of the storm [in Hungarian]. Filmtett. www.filmtett. ro/cikk/3027/fliegauf-benedek-csak-a-szel (accessed 19 Sept. 2012).

Imre, Anikó. 2005. Whiteness in post-socialist Eastern Europe: The time of the gypsies, the end of race. In: López, Alfred J., ed. Postcolonial whiteness: A critical reader on race and empire. Albany: State University Press New York. 79-103.

Iordanova, Dina. 2003. Editorial. Romanies and cinematic representation. Framework 44(2) www.frameworkonline.com/Issue44/442editorial.html (accessed 19 Sept. 2012).

Kemény, István. 2005. Roma of Hungary. Boulder, Col.: Social Science Monographs; Highland Lakes, NJ: Atlantic Research and Publications.

Shohat, Ella, and Stam, Robert. 1994. Unthinking Eurocentrism. London: Routledge.

Smith, Murray. 1995. Engaging characters. Oxford University Press.

Stam, Robert, and Spence, Louise. 1983. Colonialism, racism and representation. Screen 24(2): 2-20.

Szalai, Júlia. 2007. Nincs két ország [in Hungarian]. Budapest: Osiris.

Tomlinson, Alan and Young, Christopher. 2006. National identity and global sports events. Albany: State University of New York Press

Zolnay, János. 2012. Abusive language and discriminatory measures in Hungarian local policy. In: Stewart, Michael, ed. The Gypsy 'menace': Populism and the new antiGypsy politics. London: Hurst \& Co. 25-43. 